\title{
APLIKASI MIKORIZA PADA TANAH LAHAN REKLAMASI TAMBANG BATUBARA TERHADAP PERTUMBUHAN DAN HASIL TANAMAN KEDELAI (Glycine max L. Merrill)
}

\author{
Zulfikar $^{1}$, Eliyani ${ }^{2}$, dan Alvera Prihatini Dewi Nazari ${ }^{3}$ \\ ${ }^{1,2,3}$ Program Studi Agroekoteknologi, Fakultas Pertanian, Universitas Mulawarman, Jalan \\ Pasir Balengkong, Kampus Gunung Kelua, Samarinda 75119, Kalimantan Timur, \\ Indonesia. \\ E-Mail: zulfikarmedo94@gmail.com
}

\begin{abstract}
ABSTRAK
Aplikasi Mikoriza pada TanahLahan Reklamasi Tambang Batubara terhadap Pertumbuhan dan Hasil Tanaman Kedelai (Glycine max L. Merrill). Tujuan penelitian adalah untuk mengetahui: 1) pengaruh pemberian mikoriza padatanah lahan reklamasi tambang batubara terhadap pertumbuhan dan hasil tanaman kedelai; 2) dosis mikoriza yang memberikan pertumbuhan dan hasil terbaik terhadap tanaman kedelai.Penelitian dilaksanakan sejakbulan Februari sampai dengan Mei 2018, di Fakultas Pertanian Universitas Mulawarman.Penelitian percobaan disusun dalam Rancangan Acak Kelompok (RAK), merupakan percobaan faktor tunggal, dosis mikoriza, yang terdiri atas empat perlakuan, yaitu 0; 20; 40; dan $60 \mathrm{~g} \operatorname{tanaman}^{-1}$.Setiap perlakuan diulang $10 \mathrm{kali}$.Data hasil penelitian dianalisis dengan menggunakan sidik ragam dan dilanjutkan dengan Uji Beda Nyata Terkecil (BNT) pada taraf 5\%.Hasil penelitian menunjukkan bahwa perlakuan dosis mikoriza pada tanah lahan reklamasi tambang batubara memberikan pengaruh yang berbeda nyata terhadap tinggi tanaman umur 28 hari setelah tanam (HST), berat biji kering per tanaman dan berat 100 butir. Dosis $40 \mathrm{~g}$ mikoriza tanaman ${ }^{-1}$ memberikan pengaruh terbaik terhadap tinggi tanaman umur 28 HST $(41,11 \mathrm{~cm})$, berat biji kering per tanaman $(42,76 \mathrm{~g})$ dan berat 100 butir $(16,95 \mathrm{~g})$. Mikoriza memberikan pengaruh positif terhadap pertumbuhan dan hasil tanaman kedelai.Mikoriza $40 \mathrm{~g} \operatorname{tanaman}^{-1}$ memberikan pertumbuhan dan hasil tanaman kedelai terbaik.
\end{abstract}

Kata kunci : Kedelai, lahan reklamasi, mikoriza,tambang batubara.

\begin{abstract}
Application of Mycorrhizae on the Soil of Coal Mining Reclamation Land on The Growth and Yield of Soybean (Glycine max L. Merrill).The research was carried out to know: 1) the effect of mycorrhizae on thesoil of coal mining reclamation land on the growth and yield of soybean; 2) dose of mycorrhizae that provided the best growth and yield of soybean.The study was conducted from February until May 2018, at the Faculty of Agriculture, Mulawarman University. The experiment was arranged in Randomized Complete Block Design (RCBD), a single factor experiment, dose of miycorrhizae, consisted of four treatments, namely $0 ; 20 ; 40$; and 60 g per plant. Each treatment was replicated 10 times. Data were analyzed by analysis of variance and continued by the Least Significant Difference (LSD) test at 5\% of significant level. The results showed that the effect of mycorrhizae doses on the soil of coal mining reclamation land had significantly different on plant height at 28 days after planting (DAP), weight of dry seeds per plant and weight of 100 seeds. The dose of mycorrhizae $40 \mathrm{~g}$ plant- 1 had the best effect on plant height at 28 DAP $(41.11 \mathrm{~cm})$, weight of dry seeds per plant $(42.76 \mathrm{~g})$ and weight of 100 seeds (16.95 g). Mycorrhizae provided a positive effect on the growth and yield of soybean. Dose of mycorrhizae $40 \mathrm{~g} \mathrm{plant}^{-1}$ provided the best growth and yield of soybean.
\end{abstract}

Key words : Coal mining, mycorrhizae, reclamation land, soybean. 


\section{PENDAHULUAN}

Kedelai merupakan komoditas tanaman pangan utama ketiga setelah padi dan jagung. Permintaan kedelai untuk komsumsi, makanan (pakan) ternak dan bahan baku industri dari tahun ke tahun terus meningkat. Akan tetapi peningkatan kebutuhan kedelai tidak diimbangi dengan peningkatan produksi kedelai saat ini.

Menurut data BPS (2015), produksi kedelai di Provinsi Kalimantan Timur selama tiga tahun terakhir mengalami fluktuasi, pada Tahun 2013 sebesar $1.625 \mathrm{Mg}$ dengan luas tanam 1.1188 ha. Tahun 2014 mengalami penurunan menjadi $1.128 \mathrm{Mg}$ dengan luas tanam 995 ha, sedangkan pada Tahun 2015 mengalami peningkatan menjadi 1.661 $\mathrm{Mg}$ dengan luas tanam 1.326 ha. Berdasarkan data tersebut dapat dihitung produktivitas kedelaidari Tahun 20132015 berturut turut sebesar 1,37; 1,13 dan $1,25 \mathrm{Mg} \mathrm{ha}^{-1}$. Data di atas menunjukkan bahwa produktivitas kedelai dari tahun 2013-2015 cenderung mengalami penurunan, oleh karena itu perlu upaya peningkatan produktivitas dengan berbagai cara.

Upaya peningkatan produktivitas dalam rangka memenuhi kebutuhan kedelai dapat dilakukan dengan cara intensifikasi dan ekstensifikasi. Intensifikasi dapat dilakukan melalui penggunaan varietas unggul dan pemanfaatan mikrob yang berpotensi sebagai pupuk hayati (Arie, 2013). Sedangkan ekstensifikasi dilakukan dengan memanfaatkan lahan marginal, salah satu diantaranya lahan reklamasitambang batubara.

Menurut Simarmata (2005), pupuk hayati merupakan alternatif yang tepat untuk memperbaiki, meningkatkan dan mempertahankan kualitas tanah, sehingga mampu meningkatkan pertumbuhan dan menaikkan hasil maupun kualitas berbagai tanaman secara signifikan. Salah satu alternatif adalah pupuk hayati mikoriza. Mikoriza adalah asosiasi simbiotik antara jamur (fungi) dengan sistem perakaran tanaman tingkat tinggi. Perakaran yang diinfeksi oleh mikoriza terdapat jalinan hifa eksternal sehingga secara langsung akan meningkatkan kemampuan tanaman dalam menyerap air dan unsur hara serta meningkatkan efisiensi pemupukan (Murtilaksono, 2014).

Pemanfaatan lahan reklamasi tambang batubara sebagai media tumbuh bagi tanaman ternyata banyak menemui faktor pembatas. Lahan reklamasi tambang batubara umumnya memiliki tingkat kemasaman yang cukup tinggi, mengandung senyawa beracun dan memiliki konsentrasi hara makro $(\mathrm{N}, \mathrm{P}$, $\mathrm{K}, \mathrm{Ca}, \mathrm{Mg}$ ) yang rendah (Nurahman, 2016). Margarettha (2010), mengemukakan bahwa tanah galian batubara umumnya terbalik dari susunan awalnya. Tanah lapisan atas (top soil) berada di bawah tanah lapisan bawah (sub soil). Umumnya bahan-bahan ini ditumpuk di atas tanah-tanah yang produktif sehingga dapat menghambat pertumbuhan tanaman dan menurunkan produktivitas tanah.

Asosiasi mikoriza, baik dengan tanaman semusim maupun tanaman tahunan, mempunyai peran dalam memelihara dan memperbaiki stuktur tanah, meningkatkan serapan fosfor $(\mathrm{P})$, memperbaiki penyerapan air dan unsur hara serta meningkatkan pertumbuhan tanaman. Mikoriza berperan penting dalam meningkatkan penyerapan unsur hara oleh tanaman melalui simbiosisnya dengan cara meningkatkan luas daerah penyerapan dan mengeluarkan eksudat (asam-asam organik) yang dapat melarutkan $\mathrm{P}$ dari bentuk tidak larut (Noor, 2012).

Tujuan penelitian adalah untuk mengetahui pengaruh pemberian mikoriza pada tanah lahan reklamasi 
tambang batubara terhadap pertumbuhan dan hasil tanaman kedelai, dan untuk memperoleh dosis mikoriza yang memberikan pertumbuhan dan hasil terbaik tanaman kedelai.

\section{METODA PENELITIAN}

2.1. Tempat dan Waktu Penelitian dilaksanakan di Fakultas Pertanian Universitas Mulawarman. Pada bulan Februari-Mei 2018.

\subsection{Bahan dan Alat}

Bahan yang dipakai pada penelitian terdiri atas: tanah lahan reklamasi tambang batubara, pupuk mikoriza, benih kedelai varietas Wilis, pupuk kotoran ayam dan insektisida Alika 247ZC.

Alat yang dipakai terdiri atas: polibag berukuran $40 \mathrm{~cm} \times 50 \mathrm{~cm}$, cangkul, timbangan, gembor, meteran, kertas label, kamera, alat tulis dan karung.

\subsection{Rancangan Penelitian}

Penelitian percobaan menggunakan polibag disusun dalam Rancangan Acak Kelompok (RAK), merupakan percobaan faktor tunggal, dosis mikoriza (M), terdiri atas empat perlakuan, yaitu: $\mathrm{m}_{0}=$ tanpa pemberian mikoriza (kontrol); $\mathrm{m}_{1}=$ $20 \mathrm{~g}$ mikorizatanaman $^{-1} ; \mathrm{m}_{2}=40 \mathrm{~g}$ mikoriza $\operatorname{tanaman}^{-1}$ danm $_{3}=60 \mathrm{~g}$ mikoriza tanaman $^{-1}$. Setiap perlakuan diulang 10 kali.

\subsection{Pelaksanaan Penelitian}

Persiapan Media Tanam

Media tanam adalah campuran tanah pasca tambang dan pupuk kotoran ayam dengan perbandingan 1:1 dengan berat $13 \mathrm{~kg}$ polibag $^{-1}$.Tanah pasca tambang diambil di Palaranpada lahan bekas penambangan batubara milik PT. Kramik dengan luas areal \pm 3 ha, telah ditinggalkan dan direklamasi selama 3 tahun.

Penanaman dan Aplikasi Pupuk Mikoriza

Benih kedelai sebanyak tiga butir ditanam pada lubang tanam sedalam 3 $\mathrm{cm}$ di tengah-tengah polibag, kemudian ditutup dengan tanah. Mikoriza sesuai dosis perlakuan diberikan pada saat tanam dengan cara dimasukkan bersama-sama benih ke dalam lubang tanam pada saat tanam.

Pemeliharaan

Pemeliharaan meliputi: penyiraman, penyulaman, penjarangan, penyiangan gulma dan pengendalian hama dan penyakit secara mekanis dan kimiawi.

Panen

Panen dilakukan dengan memperhatikan ciri-ciri, yaitu polong berwarna kuning kecoklatan merata, batang sudah kering, sebagian daun sudah kering dan rontok. Panen kedelai dilakukan dengan cara mencabut tanaman pada bagian pangkal batang.

\subsection{Variabel yang Diamati}

Variabel yang diamati terdiri atas: tinggi tanaman pada umur 14, 28 dan 42 hari setelah tanam (HST), umur berbunga, umur panen, jumlah polong per tanaman, jumlah polong isi per tanaman, jumlah polong hampa per tanaman, berat biji kering per tanaman dan berat 100 butir.

\subsection{Analisis Data}

Data dianalisis menggunakan sidik ragam. Apabila pengaruh perlakuan berbeda, maka untuk membandingkan antara dua rata-rata perlakuan, dilanjutkan dengan Uji Beda Nyata Terkecil (BNT) pada taraf 5\%. 


\section{HASIL PENELITIAN DAN PEMBAHASAN}

Hasil sidik ragam aplikasi mikoriza pada tanah dari lahan reklamasi bekas tambang batubara menunjukkan berbeda tidak nyata terhadap tinggi tanaman pada umur 14dan 42 HST, umur berbunga, umur panen, jumlah polong per tanaman, jumlah polong isi per tanaman dan jumlah polong hampa per tanaman, tetapi berbeda nyata terhadap tinggi tanaman pada umur 28 HST, berat biji kering per tanaman, dan berat 100 butir. Rekapitulasi hasil penelitian disajikan pada Tabel 1 berikut.

Tabel 1. Rekapitulasi Hasil Penelitian Aplikasi Mikoriza pada Tanah Bekas Tambang Batubara terhadap Pertumbuhan dan Hasil Tanaman Kedelai

\begin{tabular}{|c|c|c|c|c|c|c|c|c|c|c|}
\hline \multirow{2}{*}{$\begin{array}{c}\text { Dosis } \\
\text { Mikoriza } \\
(\mathrm{g} \\
\text { tanaman) }\end{array}$} & \multicolumn{3}{|c|}{ Tinggi Tanaman $(\mathrm{cm})$} & \multirow{2}{*}{$\begin{array}{c}\text { Umur } \\
\text { Berbunga } \\
\text { (HST) }\end{array}$} & \multirow{2}{*}{$\begin{array}{l}\text { Umur } \\
\text { Panen } \\
\text { (HST) }\end{array}$} & \multirow{2}{*}{$\begin{array}{c}\text { Jumlah } \\
\text { Polong } \\
\text { (buah) }\end{array}$} & \multirow{2}{*}{$\begin{array}{c}\text { Jumlah } \\
\text { Polong } \\
\text { Isi } \\
\text { (buah) }\end{array}$} & \multirow{2}{*}{$\begin{array}{c}\text { Jumlah } \\
\text { Polong } \\
\text { Hampa } \\
\text { (buah) }\end{array}$} & \multirow{2}{*}{$\begin{array}{c}\text { Berat } \\
\text { Biji } \\
\text { Kering } \\
\text { (g) }\end{array}$} & \multirow{2}{*}{$\begin{array}{c}\text { Berat } \\
100 \\
\text { Butir } \\
\text { (g) }\end{array}$} \\
\hline & $\begin{array}{c}14 \\
\text { HST }\end{array}$ & $\begin{array}{c}28 \\
\text { HST }\end{array}$ & $\begin{array}{c}42 \\
\text { HST }\end{array}$ & & & & & & & \\
\hline $\begin{array}{c}\text { Sidik } \\
\text { Ragam }\end{array}$ & tn & $*$ & tn & tn & tn & tn & tn & tn & $*$ & $*$ \\
\hline kontrol & 16,27 & $33,24 a$ & 68,82 & 42,10 & 88,40 & 115,80 & 110,30 & 2,09 & $30,70 \mathrm{a}$ & $14,63 a$ \\
\hline 20 & 15,91 & $34,99 \mathrm{ab}$ & 72,40 & 40,40 & 87,80 & 113,80 & 111,80 & 1,42 & $35,67 \mathrm{ab}$ & $15,43 \mathrm{ab}$ \\
\hline 40 & 17,27 & $41,11 \mathrm{c}$ & 76,71 & 42,20 & 90,40 & 124,90 & 122,20 & 1,56 & $42,76 b$ & $16,95 \mathrm{~b}$ \\
\hline 60 & 17,33 & $39,84 b c$ & 74,99 & 42,20 & 86,60 & 142,10 & 138,40 & 1,57 & $43,14 b$ & $17,46 \mathrm{~b}$ \\
\hline BNT5\% & - & 6,19 & - & - & - & - & - & - & 10,06 & 2,13 \\
\hline
\end{tabular}

Keterangan: Angka rata-rata yang diikuti oleh huruf yang samamenunjukkan berbeda tidak nyata dengan uji BNT 5\%

\subsection{Tinggi Tanaman}

Hasil sidik ragam menunjukkan bahwa pengaruh dosis mikoriza berbeda tidak nyata terhadap tinggi tanaman pada umur 14 HST. Hal ini diduga karena pada umur 14 HST, tanaman masih muda, sistem perakaran belum berkembang dengan baik dan simbiosis antara mikoriza dan perakaran belum terbentuk secara sempurna, sehingga tanaman memanfaatkan cadangan makanan yang terdapat dalam biji, sesuai dengan penjelasan Hanafiah (2007) bahwa pada saat berkecambah, semua unsur hara yang dibutuhkan tanaman disuplai oleh biji.

Hasil sidik ragam terhadap tinggi tanaman kedelai pada umur 28 HST menunjukkan bahwa pengaruh dosis mikoriza berbeda nyata. Hasil uji BNT pada taraf 5\% menunjukkan bahwa kontrol dan $20 \mathrm{~g}$ tanaman $^{-1}$ berbeda tidak nyata, tetapi keduanya berbeda nyata dengan perlakuan dosis 40 dan $60 \mathrm{~g}$ $\operatorname{tanaman}^{-1}$. Perlakuan 40 dan $60 \mathrm{~g}$ $\operatorname{tanaman}^{-1}$ berbeda tidak nyata. Tinggi tanaman meningkat dengan dosis mikoriza 20 sampai 40 g per tanaman, tetapi menurun pada $60 \mathrm{~g}$ mikoriza tanaman $^{-1}$. Perlakuan $40 \mathrm{~g}$ tanaman ${ }^{1}$ memberikan rata-rata tinggi tanaman tertinggi $(41,11 \mathrm{~cm})$ diikuti berturut-turut oleh 60 dan $20 \mathrm{~g}$ mikoriza tanaman ${ }^{-1}$, sedangkan yang paling rendah ditunjukkan oleh perlakuan tanpa mikoriza (kontrol), yaitu 33,24 cm (Tabel 1).

Pemberian mikoriza memacu tinggi tanaman karena simbiosis dengan mikoriza menyebabkan sistem perakaran dan jangkauan perakaran menjadi lebih luas dan lebih jauh karena adanya hifa mikoriza yang sangat halus dan panjang, sehingga penyerapan air dan unsur hara, terutama fosfor, menjadi lebih baik. Hal ini sesuai dengan hasil penelitian Jannah (2011) yang menunjukkan bahwa tanaman yang diberi perlakuan mikoriza menjadi lebih tinggi dibandingkan dengan tanaman yang tidak diberikan mikoriza. Menurut Manan (1974), tanaman akan memberikan respon yang 
lebih baik melalui simbiosis dengan mikoriza, karena mikoriza secara efektif dapat meningkatkan penyerapan unsur hara makro, terutama fosfor, dan unsur hara mikro $(\mathrm{Cu}, \mathrm{Zn}$ dan $\mathrm{Mo})$.

$$
\text { Setiadi (1995) menambahkan }
$$
bahwa mikoriza berfungsi membantu proses penyerapan unsur hara oleh tanaman, khususnya fosfor, nitrogen dan kalium dari dalam tanah. Pemberian mikoriza pada prinsipnya dapat meningkatkan pertumbuhan tanaman karena kemampuannya dalam memperluas sistem perakaran melalui pembentukan hifa-hifa lateral. Selanjutnya Hardjowigeno (1995) menguraikan beberapa peran unsur-unsur tersebut, yaitu fosfor berperan dalam perkembangan akar, nitrogen berperan dalam pembentukan protein dan klorofil, sedangkan kalium mengaktifkan enzim, pembukaan stomata, proses fisiologis dan metabolisme, mempengaruhi penyerapan unsur hara lain dan perkembangan akar, $\mathrm{Cu}$ sebagai katalis respirasi, penyusun enzim, pembentukan klorofil dan metabolisme nitrogen dan karbohidrat, $\mathrm{Zn}$ berperan dalam pembentukan hormon pertumbuhan dan katalis pembentukan protein, sedangkan Mo berperan dalam pembentukan protein dan meningkatkan fiksasi nitrogen oleh bakteri simbiotik.

Hasil sidik ragam terhadap rata-rata tinggi tanaman kedelai pada umur 42 HST menunjukkan berbeda tidak nyata, hal ini diduga karena pada umur 42 HST, tanaman sudah memasuki fase pertumbuhan generatif/reproduktif dan kedelai varietas Wilis mempunyai tipe pertumbuhan determinate. Berdasarkan deskripsi, varietas Wilis berbunga pada umur \pm 39 hari dan tipe pertumbuhannya adalah determinat.Tanaman yang mempunyai tipe pertumbuhan determinat, pertumbuhan vegetatifnya akan terhenti pada saat memasuki fase generatif/reproduktif. Menurut Gardner et al. (1991), pada tumbuhan "tertentu" (determinate), transformasi kuncup penghasil daun ke pembungaan akan mengakhiri produksi daun lebih lanjut.

\subsection{Umur Berbunga dan Umur Panen}

Berdasarkan hasil sidik ragam diketahui bahwa dosis mikoriza berbeda tidak nyata terhadap umur berbunga dan umur panen tanaman kedelai.Pemberian mikoriza pada beberapa dosis (20-60 g tanaman $^{-1}$ ) memberikan pengaruh yang berbeda tidak nyata terhadap umur berbunga dan umur panen tanaman kedelai varietas Wilis, yang berdasarkan deskripsi mempunyai umur berbunga \pm 39 hari dan umur panen 85-90 hari. Hasil penelitian diperoleh umur berbunga berkisar antara 40,40-42,20HST, sedangkan umur panen antara 86,6090,40 HST (Tabel 1), tidak berbeda dengan deskripsi. Hal ini diduga disebabkan oleh faktor genetik (internal) tanaman. Darjanto dan Satifah (1984) menjelaskan bahwa faktor genotip atau faktor dalam adalah salah satu faktor yang menentukan peralihan fase vegetatif ke fase generatif tanaman, sedangkan faktor lain adalah faktor-faktor luar, seperti cahaya, air, suhu, pupuk dan lainlain.

Selain itu, tanah lahan reklamasi batubara yang dipakai pada penelitian ini mempunyai kandungan unsur hara, terutama fosfor yang tergolong rendah, yaitu sebesar 12,21 ppm. Menurut Purwa (2007), tanaman memerlukan fosfor dalam jumlah yang banyak untuk tumbuh dan berproduksi. Fosfor berperan dalam penyimpanan dan transfer energi untuk seluruh aktivitas metabolisme tanaman sehingga ketersediaan fosfor secara cukup akanmemberikan manfaat, yaitu membentuk sistem perakaran yang baik, memperkuat batang tanaman, meningkatkan hasil biji-bijian dan umbiumbian, dan mempercepat pematangan buah/biji, sehingga mempercepat masa panen. Lingga (2003) menambahkan 
bahwa ketersediaan unsur hara makro dan mikro secara cukup akan mendukung pemasakan buah dan mempercepat umur panen.

Tersedianya fosfor di dalam tanah sangat dipengaruhi oleh $\mathrm{pH}$ tanah. Reaksi $(\mathrm{pH})$ tanah yang rendah (masam) akan banyak ditemukan unsur aluminium, unsur ini selain meracuni tanaman juga mengikat fosfor sehingga tidak dapat diserap oleh tanaman. Disamping aluminium, tanah masam banyak mengandung unsur hara mikro yang bersifat meracuni tanaman, sehingga berpengaruh negatif terhadap pertumbuhan dan hasil tanaman (Winarso, 2005). Lebih lanjut Oemar dan Woerjono (1997) menyatakan bahwa jika selama fase pertumbuhan vegetatif terjadi cekaman lingkungan, dapat mengakibatkan pembentukan bunga terhambat dan gugurnya bunga dan polong muda.

\subsection{Jumlah Polong, Jumlah Polong Isi} dan Jumlah Polong Hampa per Tanaman

Hasil sidik ragam menunjukkan bahwa pengaruh dosis mikoriza berbeda tidak nyata terhadap jumlah polong per tanaman, jumlah polong isi per tanaman dan jumlah polong hampa per tanaman. Pemberian mikoriza dengan dosis yang berbeda tidak menyebabkan peningkatan jumlah polong, jumlah polong isi dan jumlah polong hampa per tanaman secara nyata diduga karena unsur hara $\mathrm{N}, \mathrm{P}$, dan $\mathrm{K}$ kurang tersedia bagi tanaman, sesuai dengan pernyataan Hardjowigeno (1995) dan Lakitan (1996) bahwa pada fase generatif/reproduktif, tanaman membutuhkan unsur $\mathrm{N}, \mathrm{P}$ dan $\mathrm{K}$. Nitrogen berperan penting dalam pembentukan klorofil dan protein, fosfor berperan dalam pembelahan sel, pembentukan bunga, buah dan biji, mempercepat pematangan, perkembangan akar, memperkuat batang, metabolisme karbohidrat dan menyimpan dan memindahkan energi, sedangkan kalium berperan dalam pembentukan pati, mengaktifkan enzim, proses fisiologis tanaman dan metabolisme sel.

Hasil analisis kimia tanah sebelum penelitian menunjukkan bahwa tanah lahan reklamasi tambang batubara yang dipakai pada penelitian ini mempunyai kandungan unsur hara $0,39 \% \mathrm{~N}$ (sedang), 12,21 ppm P (rendah) dan 34,78 ppm K (tinggi). Menurut Novizan (2002), keseimbangan unsur $\mathrm{N}, \mathrm{P}$, dan $\mathrm{K}$ akan mempengaruhi pertumbuhan tanaman. Adisarwanto (2006) menambahkan bahwa selain faktor genetik, produktivitas tanaman sangat dipengaruhi oleh unsur hara. Disamping hal tersebut di atas, tanah tersebut mempunyai $\mathrm{pH}$ 2,68, tergolong kategori sangat masam, menyebabkan unsur hara yang diperlukan tanaman pada fase generatif/reproduktif menjadi tidak tersedia, sebaliknya unsur hara mikro menjadi mudah larut, sehingga ada dalam jumlah yang banyak dan berpengaruh negatif bagi pertumbuhan dan perkembangan tanaman.

Tabel 1 menunjukkan bahwa walaupun tidak nyata, pemberian mikoriza dapat meningkatkan jumlah polong isi per tanaman dan menurunkan jumlah polong hampa pertanaman. Menurut Suprapto (1999), pada masa pembentukan polong sampai kira-kira 10 hari sebelum biji berkembang penuh, tanaman akan menggunakan fosfor secara maksimal.

\subsection{Berat Biji Kering per Tanaman}

Hasil sidik ragam menunjukkan bahwa pengaruh dosis mikoriza berbeda nyata terhadap berat biji kering kedelai. Berat biji kering per tanaman meningkat secara nyata pada pemberian mikoriza dengan dosis $40 \mathrm{~g}$ pertanaman dibandingkan dengan kontrol, tetapi berbeda tidak nyata dengan pemberian 
dosis mikoriza 20 dan $60 \mathrm{~g}$ tanaman $^{-1}$. Berat biji kering per tanaman tertinggi diperoleh pada dosis $60 \mathrm{~g}$ mikoriza tanaman $^{-1}$, yaitu 43,14 g diikuti berturutturut oleh 40, 20, dan $0 \mathrm{~g}$ mikoriza tanaman $^{-1}$, masing-masing 42,$76 ; 35,67$; dan 30,70 g per tanaman.

Hal tersebut menunjukkan kemampuan mikoriza (Fungi Mikoriza Arbuskular/FMA) dalam meningkatkan ketersediaan air dan unsur hara serta mensuplai hormon tumbuh. Fungi Mikoriza Arbuskular (FMA) dapat menyediakan unsur hara esensial yang berperan dalam pertumbuhan dan perkembangan tanaman, seperti fosfor, untuk pembentukan energi dan meningkatkan kecepatan tumbuh tanaman. Fungi Mikoriza Arbuskular (FMA) bersimbiosis dengan akar tanaman menyebabkan sistem perakaran memiliki jangkauan yang luas karena hifa-hifa dari FMA akan keluar dari bagian korteks menembus lapisan kulit luar akar tanaman. Mikoriza dengan akar hifanya meningkatkan penyerapan unsur hara, terutama fosfor, dari dalam tanah dan mentransportasikannya ke bagian tanaman yang lain seperti biji (Sukmawati, 2013). Lebih lanjut Mulyani (2002) menyatakan bahwa fosfor mempunyai peran penting dalam pengisian biji, pemasakan buah atau gabah serta dapat meningkatkan produksi biji-bijian.

Sartini (2004) menambahkan bahwa akar tanaman yang diinokulasi dengan mikoriza selain mampu meningkatkan penyerapan fosfor, juga mampu meningkatkan penyerapan unsur hara lain seperti $\mathrm{N}, \mathrm{K}, \mathrm{Mg}$ dan $\mathrm{Zn}$. Disamping itu, hifa eksternalnya membantu penyerapan air yang sangat berguna dalam fotosintesis. Hasil penelitian Astiko dan Sastrohidayat (2012) menunjukkan bahwa aplikasi mikoriza dengan pupuk kandang mampu meningkatkan konsentrasi $\mathrm{N}, \mathrm{P}, \mathrm{K}$ dan kandungan bahan organik dalam tanah sehingga meningkatkan penyerapan unsur hara, pertumbuhan dan hasil tanaman.

\subsection{Berat 100 Butir}

Hasil sidik ragam menunjukkan bahwa pengaruh dosis mikoriza berbeda nyata terhadap berat 100 butir biji kedelai. Data pada Tabel 1 menunjukkan bahwa pemberian mikoriza dengan dosis yang semakin meningkat diiringi oleh peningkatan berat 100 butir biji kedelai.Pemberian mikoriza dengan dosis $60 \mathrm{~g}$ tanaman $^{-1}$ memberikan hasil yang lebih tinggi dibandingkan perlakuan lain, walaupun berbeda tidak nyata dengan dosis 40 dan 20 g mikoriza tanaman ${ }^{-1}$. Hal ini disebabkan hifa-hifa eksternal mikoriza dapat membantu penyerapan air maupun unsur-unsur hara, terutama fosfor yang dipakai dalam proses metabolisme didalam tubuh tanaman, sehingga dapat memacu pertumbuhan dan perkembangan organ-organ produktif.

Fosfor merupakan salah satu unsur hara penyusun komponen transfer energi, asam nukleat, menstimulasi pertumbuhan awal akar dan mempercepat pertumbuhan biji (Avy, 2011). Selain itu, fosfor memegang peranan penting dalam pembentukan bunga, buah dan biji, sehingga dapat meningkatkan komponen generatif dan hasil panen. Ukuran biji yang besar akan memberikan total hasil biji kering yang tinggi. Menurut Goldsworthy dan Fisher (1996), fotosintat yang dihasilkan setelah pembungaan dan translokasi kembali fotosintat yang tersimpan dipakai untuk pengisian biji. Selanjutnya Gardner et al.(1991) menambahkan, sepanjang fase pertumbuhan generatif/reproduktif, tanaman semusim yang menghasilkan biji menjadikan biji sebagai organ penyimpanan cadangan makanan dan perkembangbiakan yang dominan. Oleh karena itu, selama pengisian biji, fotosintat yang baru terbentuk maupun 
yang tersimpan dapat digunakan untuk meningkatkan berat biji.

\section{KESIMPULAN}

Berdasarkan penelitian dan peembahasan dapat disimpulkan bahwa: 1) Dosis mikoriza pada tanahlahan reklamasitambang batubara memberikan pengaruh yang berbeda nyata terhadap tinggi tanaman kedelai umur 28 HST, berat biji kering per tanaman dan berat 100 butir kedelai. 2) Mikoriza dengan dosis $40 \mathrm{~g} \operatorname{tanaman}^{-1}$ memberikan pengaruh terbaik pada tinggi tanaman umur 28 HST $(41,11 \mathrm{~cm})$, berat biji kering per tanaman $(42,76 \mathrm{~g})$ dan berat 100 butir $(16,95 \mathrm{~g})$.

\section{DAFTAR PUSTAKA}

Adisarwanto.T. 2006. Kedelai. Penebar Swadaya, Jakarta.

Arie.2013. Swasembada Pangan. http://www.kompasiana.com/ariefe bstyo/angan- swasembadapangan_552995c8f17e614a0ad623a 8. (diakses 10 Juli 2016).

Astiko, W dan Sastrohidayat. Aplikasi pupuk organik berbasis mikoriza untuk meningkatkan hasil tanaman kedelai dibawah semi arid tropis Lombok Utara. JURNAL BUANA SAINS 12 (2012):15-20.

Avy, A.M.Pengaruh mikoriza terhadap pertumbuhan dan hasil tanaman sorgum manis (Sorghum bicolor L. Moench) pada tunggal pertama dan kedua. JURNAL FAKULTAS PERTANIAN UNIVERSITAS GADJAH MADA (2011): 8.

Badan Pusat Statistik (BPS). 2015. Data Kebutuhan Kedelai
Kalimantan Timur 2010015.http://kaltim.bps.go.id./Brs/vie w/id/59. (diakses6 April 2017).

Darjanto dan S. Satifah.1984. Pengetahuan Dasar Biologi Bunga dan Teknik Penyerbukan Silang Buatan. Gramedia, Jakarta. 156 hlm.

Delvian. Aplikasi cendawan mikoriza arsbuskula dalam reklamasi lahan kritis pasca tambang.JURNAL JURUSAN KEHUTANAN FAKULTAS PERTANIAN UNIVERSITAS SUMATERA UTARA(2004) :21.

Gardner, F.P., R.B. Pearce, dan R.L. Mitchell. 1991. Fisiologi Tanaman Budidaya. Diterjemahkan oleh: Herawati Susilo. UI-Press, Jakarta.

Goldsworthy, P.R., dan N.M. Fisher. 1996. Fisiologi Tanaman Budidaya Tropik. Diterjemahkan oleh: Tohari. Soedharoedjian (Penyunting). Gadjah Mada University Press, Yogyakarta.

Hanafiah, K.A.2007. Dasar-Dasar Ilmu Tanah. Raja Grafindo Persada, Jakarta.

Hardjowigeno, S. 1995.Ilmu Tanah. Akdemika Pressindo, Jakarta.

Jannah, H.Respon tanaman kedelai terhadap asosiasi fungi mikoriza arbuskular di lahan kering.J URNAL FAKULTAS MATEMATIKA dan IPA, IKIP Mataram 5.2 (2011).

Lakitan, B. 1996. Fisiologi Pertumbuhan dan Perkembangan Tanaman. Raja Grafindo Persada, Jakarta. 
Lingga, P. 2003. Petunjuk Penggunaan Pupuk. Penebar Swadaya, Jakarta.

Manan, S.1974. Pengaruh Mikoriza pada Pertumbuhan Semai Pinus Merkusi di Persemaian. Majalah Kehutanan Indonesia. Edisi 10.

Margarettha.2010. Pemanfaatan Tanah Tambang Batubara dengan Pupuk Hayati Mikoriza sebagai Media Tanam Jagung Manis.Universitas Jambi, Jambi.

Mulyani, S. 2002. Anatomi Tumbuhan. Kanasius, Yogyakarta.

Murtilaksono, A.Pemberian mikoriza dan pupuk kalium terhadap peningkatan produktivitas akar dan komponen hasil hanjeli (Coix lacryma jobi L.) pada lahan kering Jatinangor. JURNAL FAKULTAS PERTANIAN UNIVERSITAS PADJAJARAN (2004).

Noor, A.2012. Peranan dan Mekanisame Tanaman yang Bersimbiosis dengan Mikoriza dalam Meningkatkan Serapan Fosfat pada Tanah Masam. Prosiding Seminar Nasional Inovasi Teknologi Berbasis Ketahanan Pangan Berkelanjutan. Balai Pengkajian Teknologi Pertanian, Kalimantan Selatan.

Novizan.2002. Petunjuk Pemupukan Efektif. Agromedia Pustaka, Jakarta.
Nurahman, M.2016. Aplikasi Tandan Kosong Kelapa Sawit dengan Aktivator Larutan Mikroorganisme Limbah Udang dengan Tanaman Uji Kedelai (Glycine max L. Merrill). pada Tanah Pasca Tambang Batubara. Skripsi. Universitas Mulawarman, Samarinda.

Purwa, D.R. 2007. Petunjuk Pemupukan. Agro Media Pustaka, Jakarta

Sartini. Mikoriza arbuscular dan kascing: pengaruh terhadap pertumbuhan tanaman. JURNAL BIDANG ILMU PERTANIAN 2 (2004):3638.

Setiadi, Y. 1995. Mengenal Cendawan Mikoriza Arbuskular (CMA) dan Prospek Aplikasinya sebagai Pupuk Biologis. Makalah Lokakarya Sistem Produksi Bibit Secara Massal. IPB, Bogor.

Simarmata, T. 2005. Revitalisasi Kesehatan Ekosistem Lahan Keritis dengan Memanfaatkan Pupuk Biologis Mikoriza dalam Percepatan Pengembangan Pertanian Ekologis di Indonesia. Prosiding AMI Jambi. (Indonesia)

Sukmawati. 2013. Respon Tanaman Kedelai terhadap Penggunaan Pupuk organik, Inokulasi FMA dan Varietas Kedelai di Tanah Pasiran. Universitas Nahdlatul Wathan Mataram. 
Suprapto.1999. Bertanam Kedelai. Winarso,S. 2005. Kesuburan Tanah: Penebar Swadaya, Jakarta.

Dasar Kesehatan dan Kualitas Tanah. Gava Media, Yogyakarta.

Oemar, O, dan Woerjono.1997. Studi Metode Penyaringan Ketahanan Kedelai terhadap Kekeringan Menggunakan Larutan Polyethylene Glycol. BPPS-UGM. Program Pasca Sarjana Universitas Gadjah Mada, Yogyakarta. 